\title{
DRYING METHODS AND THEIR IMPLICATION ON QUALITY, QUANTITY AND ANTIMICROBIAL ACTIVITY OF THE ESSENTIAL OIL OF LAURUS NOBILIS L. FROM MOROCCO
}

\author{
Khadija Dahak, Hafida Bouamama, Fatiha Benkhalti and Moha Taourirte \\ Laboratory of Bio-Organic Chemistry and Macromolecular (LCBM), Department of Chemical Sciences, \\ Faculty of Science and Technology Gueliz (FSTG), Cadi Ayyad University, 40000, Marrakech, Morocco
}

Received 2014-02-11; Revised 2014-02-18; Accepted 2014-03-20

\begin{abstract}
The effects of various methods of drying on the chemical quality and antimicrobial activity of the essential oil of Laurus nobilis were studied. The most prominent component in the air-dried, fresh leaf and microwave-dried leaf oils is 1,8 Cineole $(58,8,35.62$ and $42,9 \%$ respectively). The essential oil has undergone significant chemical transformation in its monoterpenoids when the leaves of plant in the question were dried by the three different methods. The oils have screened for antimicrobial activity against both Gram positive (Staphylococcus aureus, Enterococcus hirae) and Gram negative (Escherichia coli, Pseudomonas aeruginosa) bacteria and two fungal species (Penicilium digitatum and Alternaria sp). The microbial strains tested have been found sensitive to all essential oils studied.
\end{abstract}

Keywords: Laurus Nobilis, Essentials Oil, GC/MS, Antimicrobial Activity

\section{INTRODUCTION}

The Lauraceae consisted of 52 genera and almost 3000 species. Laurus nobilis L., (bay) a member of the family named Apollo's Laurel in mythology, is a plant widely distributed in the Mediterranean countries (especially Italy and Greece and North America) and in Europe, has been used as spices in cookery and in USA as an ornamental plant (Riaz et al., 1989; Barla et al., 2007; Takaku et al., 2007; Marino et al., 2008; Derwich et al., 2009). Laurus nobilis is an evergreen tree and shrub up to $2-15 \mathrm{~m}$ height. Leaves are about $8-4 \mathrm{~cm}$ long and $2.5-4.5 \mathrm{~cm}$ wide and dark green with wavy margin. This plant is basically cultivated in many temperate parts of the world, particularly in the Mediterranean countries (Turkey, Algeria, Greece, Morocco, Portugal, Spain, Belgium and Mexico) (Demir et al., 2004; Belouahem-Abed et al., 2011). In Morocco this plant is widely used in folk medicine for their Antiseptic, stimulating, stomachic and sudorific properties (Ozcan and Chalchat, 2005). Many studies on the antimicrobial activity of the essential oils of Laurus nobilis species have been reported (Olivera et al. 2007; Derwich et al., 2009; Keskin et al., 2010; Sellami et al., 2011; Jemaa et al., 2012; Fethi et al., 2013). To the best of our knowledge, there are not previous reports on the relation between the effects of drying methods and the antimicrobial activity of the essential oil of Laurus nobilis. In this study, we present the effects of various drying methods on the chemical compositions, the yield and antimicrobial activity of the essential oils leaves of Laurus nobilis from Morocco.

\section{MATERIALS AND METHODS}

\subsection{Plant Materials}

The leaves of the Laurus nobilis were gathered from the mountains of ouaouizerth, the area of Azilal

Corresponding Auther: Khadija Dahak, Laboratory of Bio-Organic Chemistry and Macromolecular (LCBM), Department of Chemical Sciences, Faculty of Science and Technology Gueliz (FSTG), Cadi Ayyad University, Marrakech, Morocco 
(Morocco) in March 2008. They were identified by Prof. Ahmed OUHAMMOU from the Faculty of Sciences SEMLALIA of Marrakech (Cadi Ayyad University, Morocco). Voucher specimen was deposited at the Herbarium of the faculty of sciences SEMLALIA (Mark 7822). The plant material is divided into three portions of $500 \mathrm{~g}$. The first portion is dried eight days in the laboratory, under normal air and at room temperature $\left(25^{\circ} \mathrm{C}\right)$ (air-dried), the second portion is dried in the micro-wave (whirlpool, model AV $\mathrm{M} 510 / \mathrm{Wp} / \mathrm{Wh}$ at a MW frequency of $2450 \mathrm{MHz}$, input $1330 \mathrm{~W}$ and supply $230 \mathrm{~V}-50 \mathrm{~Hz}$ ) (MW-dried), which is maintained in $400 \mathrm{~W}$ during $5 \mathrm{~min}$, the third part is extracted immediately with the state fresh (Fresh).

\subsection{Extraction of the Essential Oils}

The essential oils of the fresh and dried Leaves of Laurus nobilis were obtained by hydrodistillation using a Clevenger-type apparatus in $4 \mathrm{~h}$ time. For this purpose we put $500 \mathrm{~g}$ the plant material in direct contact with water inside a flask over a heat source. The flask was connected to a condenser allowing the accumulation water vapor loaded with essential oil droplets. The next step would be collecting the essential oil in a graduated burette where the volume was read directly. The essential oil was dried over anhydrous sodium sulfate, filtered and stored at $4{ }^{\circ} \mathrm{C}$ in amber glass vials until analysis and antimicrobial tests. The essential oils yields were estimated according to leaves by using the following Equation 1:

$\operatorname{RHE}(\%)=(\mathrm{mHE} / \mathrm{mS}) * 100$

Where:

$\mathrm{mHE}=$ Essential oil mass $(\mathrm{g})$

$\mathrm{mS}=$ Dry or fresh leaves mass $(\mathrm{g})$

RHE $=$ Essential oil yield (\%)

\subsection{Gas Chromatography/mass Spectrometry Analysis (GC/MS).}

Essential oils of dry leaves of Laurus nobilis were analyzed by GC-MS: Trace GC ULTRA, equipped with VB-5 fused silica capillary column $(5 \%$ phenyl Methylpolysiloxane, $30 \mathrm{~m}, 0.25 \mathrm{~mm}$; film thickness 0.25 $\mu \mathrm{m}$ ), coupled to mass spectrometer (Polaris Q MS Ion Trap, ion source $200^{\circ} \mathrm{C}, 70 \mathrm{ev}$ ). The oven temperature was programmed from 40 to $80^{\circ} \mathrm{C}$ at a rate of $4^{\circ} \mathrm{C} / \mathrm{min}$ and then programmed to $100^{\circ} \mathrm{C}$ at a rate of $1^{\circ} \mathrm{C} / \mathrm{min}$ and from 100 to $300^{\circ} \mathrm{C}$ at a rate of $20^{\circ} \mathrm{C} / \mathrm{min}$ and then kept constant at $300^{\circ} \mathrm{C}$ for $2 \mathrm{~min}$. The injector temperature was $220^{\circ} \mathrm{C}$; split ratio was $1: 10$. Diluted sample $(1 / 10$, $\mathrm{v} / \mathrm{v}$, in Methanol) of $1 \mu \mathrm{L}$ was injected; helium was used as the carrier gas at $1.4 \mathrm{~mL} \mathrm{~min}^{-1}$.

\subsection{Identification of the constituents}

Through using a formula as described by Dool and Kratz (1963) on VB-5 column. The Retention Indices (RI) were calculated by comparing the retention times of the eluting peaks with those of $\mathrm{C}_{8}-\mathrm{C}_{20}$ n-alkanes. Identification of the essential oil components was made by comparing their retention indices and mass spectra with the NIST library (NIST/EPA/NIH MASS SPECTRAL LIBRARY Version 2.0 a, build Jul. 1 2002) as well as by comparing them with those reported in the literature. The components from the gas chromatography-mass spectral analysis are reported in Table 1.

\subsection{Antimicrobial Tests}

\subsubsection{Microbial Strains}

Gram (+): Staphylococcus aureus (CIP 53.154), Enterococcus hirae (CIP 58.55), Gram (-): Pseudomonas aeruginosa (CIP A22), Escherichia coli (CIP 54.8). Yeast: Candida albicans (ATCC 2091) and two fungal phytopathogenics species (Penicilium digitatum and Alternaria $\mathrm{sp}$ ) isolated from specimens food (Bioprocesses engineering unit, Faculty of Sciences and Technology, Cadi Ayyad University of Marrakech, Morocco).

\subsubsection{Preparation of Test Microorganisms}

Bacterial strains were cultured at $35^{\circ} \mathrm{C}$ in MuellerHinton broth for $24 \mathrm{~h}$, while the fungal strains cultured at $30^{\circ} \mathrm{C}$ using Sabouraud broth for $48 \mathrm{~h}$. Before the bacterial experiments were carried out, $5 \mathrm{~mL}$ of broth (Mueller-Hinton and Sabouraud broth) was inoculated with newly harvested bacteria and incubated for $18 \mathrm{~h}$ at the adequate temperature. These bacterial suspensions (approximately $10^{6} \mathrm{cfu} / \mathrm{mL}$ ) were used to inoculate the test medium containing the essential oil.

Table 1. Weight difference between fresh and dry cases of Laurus nobilis

\begin{tabular}{lccc}
\hline Plant & Fresh & Air- dried & MW-dried \\
\hline Weight $(\mathrm{g})$ & 500 & 275 & 150 \\
& 250 & 138 & 76 \\
Weight decrease (\%) & 0 & 45 & 70 \\
\hline
\end{tabular}




\subsubsection{Antimicrobial Activity Test}

The antimicrobial activity of the selected essential oils was determined by dilution of essential oils in solid medium (agar) method (Ruberto and Baratta, 2000; Pintore et al., 2002; Dobre and Niculita, 2012). In each sterile Petri dishes $(5 \mathrm{~cm}$ in diameter), were mixed aseptically $1 \mathrm{~mL}$ of the essential oil with a concentration determine dissolved in DMSO (dimethylesulfoxide 5\%) and $10 \mathrm{~mL}$ of culture medium still in a state of superfusion (Mueller-Hinton for bacteria and Sabouraud yeast strains). The Petri dishes were carefully agitated and let cool during $30 \mathrm{~min}$ for the solidification of the medium. In each dishes, the mixture was inoculated by spot with $1 \mu \mathrm{L}$ of bacterial suspension. But for yeast, the discs (1 $\mathrm{mm}$ in diameter) of a $48 \mathrm{~h}$ culture were deposited, surface in bottom, in plates containing the mixture. Dilutions of the oils within a concentration range of 20 to $0,15 \mathrm{mg} \mathrm{mL}^{-1}$ were also carried out.

The Petri dishes were incubated at $37^{\circ} \mathrm{C}$ for $24 \mathrm{~h}$ and $30^{\circ} \mathrm{C}$ for $48 \mathrm{~h}$ for bacterial strain and fungal strain, respectively. Amoxicillin (Amx) and Amphotericine B (Aph B) were used as the reference antibiotic control for bacteria and fungi respectively. After incubation Petri dishes were evaluated for the presence or the absence of colonies. For each treatment, the non-presence of colonies on all dishes tested was considered as an inhibitory effect. The lowest concentration of essential oil required to inhibit the growth of fungi and bacteria was designated as the Minimal Inhibitory Concentration (MIC). The experiments were repeated at least twice.

\section{RESULTS}

The Table 1 shows that the drying by microwave allows diminution of $70 \%$ by weight of Laurus nobilis against air-dried plant does not exceed $45 \%$.

The Table 2 shows that the GC-MS analysis of the essential oil from different methods leaves drying of Laurus nobilis resulted in the identification of forty compounds. The essential oil yields of the fresh and leaves dried in normal air and by micro-wave were 1,64 , 1,84 and $0,96 \%$ respectively. The reduction of the oil yield caused by microwave $(0,96 \%)$ is clearly related to the energy absorption. In the different leaves essential oils of Laurus nobilis (Fresh, Air-dried and MW-dried) 25, 14 and 13 compound were identified, which made up $99 ; 98$ and $80 \%$ of the total essential oil respectively.

The major compounds detected in the leaves fresh oils are 1,8 cineole $(58,88 \%)$, endo-Fenchol $(13,26 \%)$ and $\alpha$-camphenal $(9,27 \%)$. In the air-dried oils, the most major components are: 1,8 cineole $(35,62 \%), \alpha-$ camphenal (9,65\%), Myrtenal (8,86\%), 3-carene $(7,88 \%)$ and endo-Fenchol (6,35\%). The major components of oil dried by micro-wave are $1,8 \mathrm{Cineole}$ $(42,99 \%)$ and n-hexenal $(12,24 \%)$.

Table 3 presents the MIC of different essential oils determined for two Gram positive and two gram negative bacteria and two fungal species using the dilution technique of essential oils on solid media (agar). The results show that all the essential oil tested have a substantial inhibitory effect on all bacterial and fungal strains but they are different.

\section{DISCUSSION}

\subsection{Yield and Chemical Composition of Essential Oils}

In Table 2, extraction results show a clear difference in yield which was turned down after drying the studied plants by micro-wave. This confirms many results in studies carried out in this area by mentioning the evident effect of drying (Jerkovic et al., 2001; Okoh et al., 2008; Sellami et al., 2011; Fethi et al., 2013), whether on yield decrease or on the change of essential oil chemical composition by concentration decrease of some constituents. Englund and Ralpha, (2000; Maroto et al., 2004; Okoh et al., 2008; Al-Jaber et al., 2012). Our studies have shown a slight increase in yield of essential oil after air drying. Even if there is a decrease weight. (Combrinck et al., 2006; Sellami et al., 2011). On the other hand, the decrease in weight caused by MWdried is expressed by the decrease in moisture to preserve the product for extended shelf life (Muller and Heind 2006; Rocha et al., 2011). While drying plants contributes significantly to the loss of moisture which is expressed by the water content and the set of which is among other volatile fluids. So, the essential oil is one of the most important components of the moisture in plant especially when his constituents are very volatile. On balance, we can say that the microwave drying has a clear effect on reducing oil yield. It seems very important to make the extraction in the case of airdried, several reasons to maintain the maximum amount of these essential oils. The optimization of this drying process contributes to physical, chemical and microbiological stability of the medicinal herbs.

The oils consisted of a mixed products basically known of monoterpene and sesquiterpene. The composition of essential oil of L. nobilis has also been reported in previous research (Fiorini et al., 1997; Simic et al., 2004; Dadalioglu and Evrendilek, 2004; Sangun et al., 2007; Jemaa et al., 2012; Fethi et al., 2013). 
Table 2. Chemical composition of the essential oil from Laurus nobilis leaves using deferent drying methods

\begin{tabular}{|c|c|c|c|c|}
\hline \multirow[b]{2}{*}{$\mathrm{RI}^{\mathrm{a}}$} & \multirow[b]{2}{*}{ Compounds ${ }^{\mathrm{b}}$} & \multicolumn{3}{|l|}{$\%$} \\
\hline & & Fresh & Air-dried & MW-dried \\
\hline$\overline{803}$ & n-hexenal & - & - & 12,24 \\
\hline 826 & (Z)-3-Hexenol & - & - & 1,09 \\
\hline 904 & Heptanal & - & - & 1,92 \\
\hline 952 & Myrcene & - & 0,65 & - \\
\hline 959 & Camphene & 0,49 & 4,87 & - \\
\hline 973 & Sabinene & - & 0,67 & - \\
\hline 1000 & dehydro-1,8 Cineole & 2,6 & - & - \\
\hline 1001 & 3 -carene & - & 7,88 & - \\
\hline 1003 & $\alpha$-phellandrene & - & 4,41 & - \\
\hline 1020 & $\alpha$-Terpinene & - & 0,94 & - \\
\hline 1032 & Limonene & - & 0,42 & - \\
\hline 1045 & Cis- $\beta$-ocimene & - & 1,21 & - \\
\hline 1052 & $\gamma$-Terpinene & - & 0,63 & - \\
\hline 1060 & 1,8 Cineole & 58,88 & 35,62 & 42,99 \\
\hline 1088 & $\alpha$-Terpinolene & & 2,1 & - \\
\hline 1105 & trans-Sabinene hydrate & 3,51 & 3,29 & - \\
\hline 1106 & linalool & - & - & 2,28 \\
\hline 1112 & endo-Fenchol & 13,26 & 6,35 & 3,6 \\
\hline 1118 & cis-p-Menth-2-en-1-ol & 0,78 & - & 3,2 \\
\hline 1132 & $\alpha$-camphenal & 9,27 & 9,65 & - \\
\hline 1134 & $\alpha$-campholenal & - & - & 2,64 \\
\hline 1147 & Camphor & 1,95 & - & - \\
\hline 1157 & trans-verbenol & 0,74 & 1,14 & - \\
\hline 1162 & Borneol & 0,53 & 0,89 & - \\
\hline 1178 & 4-Terpineol & - & 0,43 & - \\
\hline 1194 & thuj-3-en-10-al & 3,29 & - & - \\
\hline 1199 & Myrtenal & 1,68 & 8,86 & - \\
\hline 1203 & Verbenone & - & 0,43 & - \\
\hline 1234 & Geraniol (Nerol) & - & 0,93 & - \\
\hline 1243 & Linalyl acetate & 1,91 & 3,22 & - \\
\hline 1262 & trans-Caryophyllene & - & 0,33 & - \\
\hline 1348 & $\alpha$-Terpinyl acetate & - & 0,45 & - \\
\hline 1500 & Germacrene-D & - & 2,08 & - \\
\hline 1532 & $\delta$-cadinene & - & 0,64 & - \\
\hline 1885 & Unknown & - & - & 1,61 \\
\hline 1895 & Unknown & - & - & 1,58 \\
\hline 1980 & Eremanthin (vanillosimin) & - & - & 1,42 \\
\hline 2056 & Unknown & - & - & 1,07 \\
\hline 2080 & $\alpha$-Cadinol & - & - & 2,1 \\
\hline 2093 & Eugenol & - & - & 1,97 \\
\hline Total i & & 99 & 98 & 80 \\
\hline Yield & & 1,64 & 1,84 & 0,96 \\
\hline
\end{tabular}

${ }^{\mathrm{a}}$ Retention indices (RI) on VB-5; ${ }^{\mathrm{b}}$ Compounds listed in order of elution from a non-polar VB-5 column; - not detected

And then, the essential oils composition show a similar pattern to those published for other geographical regions, 1.8-cineole was reported as the major component in the essential oil from Turkey (Dadalioglu and Evrendilek, 2004; Ozcan and Chalchat, 2005; Kilic et al., 2005), China (Zheng-kui et al., 1990), Tunisia (Bouzouita et al., 2001), Mediterranean (Zola et al., 1977), Argentina (Huergo and Retamar, 1978) and Italy (Flamini et al., 2007). The following compounds: Camphene, trans-sabinene hydrate, endo-fenchol, $\alpha$ - camphenal, linalyl acetate and myrtenale were only identified at the fresh and air-dried oils. These compounds were vaporized or transformed to other compounds in the micro-wave dried leaves. The results show that only micro-wave drying brought about significant losses of the major compounds ( $\alpha$ camphenal, myrtenal and 3-carene) in the essential oil when compared to the fresh and air-dried plant material. This might be due to some chemical transformations during the process of drying. 
Khadija Dahak et al. / OnLine Journal of Biological Sciences 14 (2): 94-101, 2014

Table 3. Antibacterial and antifungal activities of Laurus nobils essential oils from Morocco.

\begin{tabular}{|c|c|c|c|c|c|c|}
\hline \multicolumn{7}{|c|}{$\mathrm{MIC}^{\mathrm{a}} \mathrm{mg} / \mathrm{ml}$} \\
\hline & \multicolumn{2}{|c|}{ Bacteria (Gram-) } & \multicolumn{2}{|c|}{ Bacteria $($ Gram +$)$} & \multicolumn{2}{|l|}{ Fungal } \\
\hline & E. coli & P. aeruginosa & S. aureus & E. hirae & P. digitatum & Alternaria sp \\
\hline Fresh & 3,5 & 4,25 & 2 & 2,5 & 2 & 2,25 \\
\hline Air-dried & 3 & 3,5 & 1,5 & 1,75 & 1,75 & 1,5 \\
\hline MW-dried & 3,25 & 3,25 & 1,75 & 2,25 & 2 & 1,5 \\
\hline Amx & 0,0035 & 0,00025 & 0,00025 & 0,00052 & - & - \\
\hline Aph B & - & - & - & - & 0,00156 & 0,002 \\
\hline
\end{tabular}

${ }^{\mathrm{a}}$ Minimal inhibitory concentration of essential oil in $\mathrm{mg} / \mathrm{ml}$.

Effect of drying on the release or retention of volatiles depends on the type of composition (Fathi and Sefidkon, 2012). In general, the best results were observed with airdrying. Also, our result is in agreement with results of Ghasemi et al., 2013; Pirbalouti et al., 2013.

\subsection{Antimicrobial Activity}

The aim of this experiment has been basically to evaluate the antimicrobial activity of laurel essential oil. The results in this study indicate that the MIC of essential oil obtained from fresh leaves is higher than the essential oil from MW-dried leaves followed by the essential oil from Air-dried which has the best antimicrobial activity. This difference may be due to the difference in the composition of essential oils caused by various methods of drying of leaves of Laurus nobilis. Gram-positives ( $S$. aureus and $E$. Herea) have been the most sensitive strain tested to the all essential oils of $L$. nobilis. Modest activities are observed against Gram-negatives (E. coli and P. Aeruginosa) with MIC of 3- 4,25 mg mL $\mathrm{mL}^{-1}$. Same results found by Ghazi (2013) and Verma et al. (2013) opposite of those found by (Imelouane et al., 2009a). The synergy between terpenes (linalool), oxides (1,8 cineole) and monoterpenes (camphene, $\alpha$-pinene) gives to the essential oil of Laurel a good antibacterial activity (Ouibrahim et al., 2013). The major components of this oil, 1.8- cineole, have been known to exhibit antimicrobial activity against the bacterial strains (E. Coli, P. Aeruginosa, S. Typhi, S. Aurus, Rhizobium leguminosarum and Bacillus subtilis) (Sivropoulou et al., 1997). In general, the antimicrobial activities of essential oils are difficult to correlate a specific compound due to their complexity and variability Imelouane et al., (2009b). Belletti et al. (2004), showed that the antimicrobial activities have been mainly explained through $\mathrm{C}_{10}$ and $\mathrm{C}_{15}$ terpenes with aromatic rings and phenolic hydroxyl groups able to form hydrogen bonds with active sites of the target enzymes, although other active terpenes, as well as alcohols, aldehydes and esters can contribute to the overall antimicrobial effect of essential oils. On the other hand, enantiomers of $\alpha$-pinene, limonene and linalool have a strong antibacterial activity (Filipowicz et al., 2003; Koji et al., 2004; Tampieri et al., 2005). Pinene-type monoterpene hydrocarbons ( $\alpha$-pinene and $\beta$-pinene) are well known chemicals having antimicrobial potentials (Dorman and deans, 2000; Rios and Recio, 2005; Kazemi et al., 2012).

\section{CONCLUSION}

This study has revealed a high level of chemical composition of the essential oils of Laurus nobilis originated from azilal (Morocco). The effects of various drying methods on the chemical compositions, yield and antimicrobial activity of the essential oils leaves of Laurus nobils from Morocco have been studied. Our data shown that Air-drying is the best method of drying the leaves of Laurus nobilis because its low MIC is against all strains tested bacteria and fungi. Drying of aromatic plants affects significantly in the quantity and the quality of essential oils. Therefore, the extraction from air-dried plants not only economically increases the yield for industries, but also, saves the pharmaceutical quality of essential oils. Finally, we can say that the oil can be proposed as a valuable source in the foods as a natural antimicrobial agent. This study enables us for further attention to identify the active compounds responsible for the biological activity of this plant and explained the exact mechanism of action by which essential oils exert their antimicrobial effect. More studies conducted to determine the antioxidant activity of these oils.

\section{REFERENCES}

Al-Jaber, H.I., M.A. Al-Qudah, L.M. Barhoumi, I.F. Abaza and F.U. Afifi, 2012. Essential oil composition of the aerial parts of fresh and air-dried Salvia palaestina Benth. (lamiaceae) growing wild in Jordan. Natural Product Res., 26:1179-1187. DOI: $10.1080 / 14786419.2010 .543901$ 
Barla, A., G. Topcu, S. Oksuz, G. Tumen and D.G.I. Kingston, 2007. Identification of cytotoxic sesquiterpenes from Laurus nobilis. L. Food Chem. 104: 1478-1484. DOI: 10.1016/j.foodchem.2007.02.019

Belletti, N., M. Ndagihimana., C. Sisto, M. Guerzoni and R. Lanciotti et al., 2004. Evaluation of the antimicrobial activity of citrus essences on saccharomyces cerevisae. J. Agric. Food Chem. 52: 6932-6938. PMID: 15537299

Belouahem-Abed, D., F. Belouahem, M. Benslama, G.D. Belair and D. Serge et al., 2011. Alder forests of Numidia (N.E. Algeria): Floristic biodiversity, vulnerability and conservation. Comptes Rendus Biol., 334: 61-73. DOI: 10.1016/j.crvi.2010.10.005

Bouzouita, N., A. Nafti, M. Chaabouni, G. Lognay and M. Marlier et al., 2001. Chemical composition of Laurus nobilis oil from tunisia. J. Essent Oil Res., 13: 116-117. DOI: 10.1080/10412905.2001.9699631

Combrinck, S., A.A. Bosman, B.M. Botha, W. Du Plooy and R.I. McCrindle et al., 2006. Effects of post harvest drying on the essential oil and glandular trichomes of lippia scaberrima sond. J. of Essential Oil Res., 18: 80-84.

Dadalioglu, I. and G.A. Evrendilek, 2004. Chemical composition and antibacterial effect of essential oils of Turkish Oregano (Origanum minutifolium), Bay Laurel (Laurus nobilis), Spanish Levander (Lavandula stoechas L.) and Fennel (Foeniculum vulgare), on common Food borne pathogen. J. Agric. Food Chem., 52: 8255-8260.

Demir, V., T. Gunhan, A.K. Yagcioglu and A. Degirmencioglu, 2004. Mathematical modelling and the determination of some quality parameters of airdried bay leaves. Biosyst. Eng., 88: 325-335. DOI : 10.1016/j.biosystemseng.2004.04.005

Derwich, E., Z. Benziane and A. Boukir, S. Mohamed, B. Abdellah 2009. Chemical composition and antibacterial activity of leaves essential oil of Laurus nobilis from Morocco. Australien J. Basic Applied Sci., 3: 3818-3824.

Dobre, A. A. and P. Niculita, 2012. Antibacterial profile of essential oils against pathogen bacteria. Bull. Univ. Agric. Sci. Vet. Med. Cluj-Napoca, 69: 255261.

Dool, V.D.H. and P.D. Kratz, 1963. A generalization of the retention index system including linear temperature programmed gas-liquid partition chromatography. J. Chromatography, 11: 463-471. DOI: $10.1016 / \mathrm{S} 0021-9673(01) 80947-\mathrm{X}$
Dorman, H.J.D and S.G. Deans, 2000. Antimicrobial agents from plants: Antibacterial activity of plant volatile oils. J. Applied Microbiol., 88: 308-316. DOI: 10.1046/j.1365-2672.2000.00969.x

Englund, F. and M.N. Ralph, 2000. Monoterpenes in Scots pine and Norway spruce and their emission during kiln drying. Holzforschung, 54: 449-456. DOI: $10.1515 /$ HF.2000.075

Fathi, E. and F. Sefidkon, 2012. Influence of drying and extraction methods on yield and chemical composition of the essential oil of Eucalyptus sargentii. J. Agric. Sci. Technol., 14: 1035-1042.

Fethi, B., M.A. Abdoune, A. Khadir and M. Bendahou, 2013. Drying effect on yield and antimicrobial activity of essential oils. Int. J. Med. Aromatic Plants, 3: 93-101.

Filipowicz, N., M. Kaminski, J. Kurlenda and M. Asztemborska, 2003. Antibacterial and antifungal activity of juniper berry oil and its selected components. Phytotherapy Res., 17: 227-231. PMID: 12672151

Fiorini, C., I. Fouraste, B. David and M. Bessiere, 1997. Composition of the flower, leaf and stem essential oils from Laurus nobilis. Flavour Fragrance J., 12: 91-93. DOI: 10.1002/(SICI)10991026(199703)12:2<91::AID-FFJ623>3.0.CO;2-3

Flamini, G., M. Tebano, P. Cioni, L. Ceccarini and S. Simone et al., 2007. Comparison between the conventional method of extraction of essential oil of Laurus nobilis L. and a novel method which uses microwaves applied in situ, without resorting to an oven. J. Chromatogrphy A, 1143: 36-40. DOI: $10.1016 /$ j.chroma.2007.01.031

Ghasemi, M., M. Jafarpour and F. Mortazeinezhad, 2013. Effect of different drying methods on the quality and quantity of the essential oil of lemon balm (Melissa officinalis L.). Int. J. Agric. Crop Sci., 6: 501-504

Ghazi, M.S., 2013. Comparative study of in vitro antibacterial activity of miswak extracts and different toothpastes. Am. J. Agric. Biol. Sci., 8: 82-88.

Huergo, H. and J. Retamar, 1978. El aceite esencial de bay (Laurus nobilis L). Riv. EPPOS., 60: 635-637.

Imelouane, B., A. Elbachiri, M. Ankit, H. Benzeid and K. Khedid, 2009a. Physico-chemical compositions and antimicrobial activity of essential oil of Eastern Moroccan lavandula dentata. Int. J. Agric. Biol., 11 :113-118. 
Imelouane, B., H. Amhamdi, J.P. Wathelet, M. Ankit and K. Khedid et al., 2009b. Chemical composition and antimicrobial activity of essential oil of thyme (thymus vulgaris) from Eastern Morocco. Int. J. Agric. Biol., 11: 205-208.

Jemaa, J.M.B., N. Tersim, K.T. Toudert and M. L. Khouja, 2012. Insecticidal activities of essential oils from leaves of Laurus nobilis L. from Tunisia, Algeria and Morocco and comparative chemical composition. J. Stored Products Res., 48: 97-104. DOI: 10.1016/j.jspr.2011.10.003

Jerkovic, I., J. Mastelic and M. Milos, 2001. The impact of both the season of collection and drying on the volatile constituents of origanum vulgare L. ssp. hirtum grown wild in Croatia. Int. J. Food Sci. Technol., 36: 649-654. DOI: 10.1046/j.13652621.2001.00502.x

Kazemi, M., E. Mousavi and N. Bandrez, 2012. Chemical compositions and antibacterial activity of the essential oils of Thymus vulgaris and Tanacetum parthenium. Res. J. Soil Biol., 4: 21-31.

Keskin, D., D. Oskay and M. Oskay, 2010. Antimicrobial activity of selected plant spices marketed in the West Anatolia. Int. J. Agric. Biol., 12: 916-920.

Kilic, A., H. Kollmannsberger and S. Nitz, 2005. Glycosidically bound volatiles and flavor precursors in Laurus nobilis L. J. Agric. Food Chem., 53: 22312235. DOI:10.1021/jf040373+

Koji, Y., T. Yamamoto, Y. Kawai and N. Inoue, 2004. Enhancement of antilisterial activity of essentials oil constituents by nisin and diglycerol fatty acid ester. Food Microbiol., 21: 283-289. DOI: 10.1016/j.fm.2003.08.009

Marino, D.S., M. Iorizzi and F. Zollo, 2008. Antioxidant activity and biological properties of phytochemicals in vegetables and spices (Capsicum, Laurus Foeniculum). Elec. J. Environ., Agric. Food Chem., 7: 3174-3177.

Maroto, D.M.C., E.S. Palomo, L. Castro, M.A.G.Vinas and M.S. Perez-Coello, 2004. Changes produced in the aroma compounds and structural integrity of basil (Ocimum basilicum L.) during drying. J. Sci. Food Agric., 84: 20702076. DOI: $10.1002 /$ jsfa.1921

Muller, J. and A. Heindl, 2006. Drying of Medicinal Plants. In: Medicinal and Aromatic Plants, Bogers, R.J., L.E. Craker and D. Lange (Eds)., Springer, Dordrecht, ISBN-10: 1402054475, pp: 237-252.
Okoh, O.O., A.P. Sadimenko, O.T. Asekum and A.J. Afolayan, 2008. The effects of drying on the chemical components of essential oils of calendula officinalis L. Afr. J. Biotechnol., 7: 1500-1502.

Olivera, P., J. Mila and M. Mladen, 2007. Chemical composition and antioxidant activity of free volatile aglycones from laurel( Laurus nobilis L.) compared to its essential oil. Croatica Chemical ACTA CCACAA, 80: 121-126.

Ouibrahim, A., Y. Tlili-Ait-kaki, S. Bennadja, S. Amrouni and A.G. Djahoudi et al., 2013. Evaluation of antibacterial activity of Laurus nobilis L., Rosmarinus officinalis L. and Ocimum basilicum L. from Northeast of Algeria. Afr. J. Microbiol. Res., 7: 4968-4973. DOI: 10.5897/AJMR2012.2390

Ozcan, M. and J. Chalchat, 2005. Effect of different locations on the chemical composition of essential oils of bay (Laurus nobilis L.) leaves growing wild in Turkey. J. Med. Food, 8: 408-411.

Pintore, G., M. Usai, P. Bradesi, C. Juliano and G. Boatto et al., 2002. Chemical composition and antimicrobial activity of Rosmarinus officinalis L. oils from Sardinia and Corsica. Flavour Fragrance J., 17: 15-19. DOI: 10.1002/ffj.1022

Pirbalouti, A.G., M. Oraie, M. Pouriamehr and E.S. Babadi, 2013. Effects of drying methods on qualitative and quantitative of the essential oil of Bakhtiari savory (Satureja bachtiarica Bunge). Ind. Crops Products, 46: 324-327. DOI: 10.1016/j.indcrop.2013.02.014

Riaz, M., C. Ashraf and F. Chaudhary, 1989. Studies of the essential oil of the Pakistani Laurus nobilis Linn. in different seasons. Pak. J. Sci. Indust. Res., 32: 33- 35 .

Rios, J.L. and M.C. Recio, 2005. Medicinal plants and antimicrobial activity. J. Ethnopharmacol., 100: 8084. DOI: 10.1016/j.jep.2005.04.025

Rocha, R.P., E.C. Melo and L.L. Radunz, 2011. Influence of drying process on the quality of medicinal plants: A review. J. Med. Plants Res., 5: 7076-7084.

Ruberto, G. and M.T. Baratta, 2000. Antioxidant activity of selected essential oil components in two lipid model systems. Food Chem., 69: 167-174. DOI: 10.1016/S0308-8146(99)00247-2 
Sangun, M.K., E. Aydin, M. Timur, H. Karadeniz and M. Caliskan et al., 2007. Comparison of chemical composition of the essential oil of Laurus nobilis L. leaves and fruits from different regions of Hatay, Turkey. J. Environ. Biol., 28: 731-733. PMID: 18405104

Sellami, I.H., W.A. Wannes, I. Bettaieb, S. Berrima and T. Chahed et al., 2011. Qualitative and quantitative changes in the essential oil of Laurus nobilis L. leaves as affected by different drying methods. Food Chem., 126: 691-697. DOI: 10.1016/j.foodchem.2010.11.022

Simic, A., M.D. Sokovic, M. Ristic, G.S. Jovanovic and J. Vukojevic et al., 2004. The chemical composition of some Lauraceae essential oils and their antifungal activities. Phytotherapy Res., 18: 713-717. PMID: 15478207

Sivropoulou, A., C. Nikolaou, E. Papanikolaou, S. Kokkini and T. Lanaras et al., 1997. Antimicrobial, cytotoxic and antiviral activities of Salvia fruticosa essential oil. J. Agric. Food Chem., 45: 3197-3201. DOI: $10.1021 / \mathrm{j} 970031 \mathrm{~m}$
Takaku, S., A. William and N.S. William, 2007. Leaf essential oil composition of 10 species of ocotea (Lauraceae) from monteverde, Costa Rica. Biochem. Systemat. Ecol., 35: 525-532. DOI: 10.1016/j.bse.2007.02.003

Tampieri, M.P., R. Galuppi, F. Macchioni, M.S. Carelle and L. Falcioni et al., 2005. The inhibition of Candida albicans by selected essential oils and their major components. Mycopathologia, 159: 339-345. DOI: $10.1007 / \mathrm{s} 11046-003-4790-5$

Verma, S., T. Mohanta, T. Revathy, K. Suthindhiran and M.A. Jayasri, 2013. Phytochemical and pharmacological evaluation of selected plants. Am. J. Biochem. Biotechnol., 9: 291-299.

Zheng-kui, L., H. Ying-fang, G. Guo-ping and Yu-hong, 1990. Chemical constituents of the essential oils from the leaves of Laurus nobilis and tendency in changes of the constituents month by month. Acta. Bot. Sin., 32: 878-882.

Zola, A., L. Le Vanda and F. Guthbord, 1977. L'huile essentielle de Laurier noble. Riv. It. EPPOS, 59: 374-380. 